\title{
Grounding the Vision of Religious Moderation as a Strategic Step in Preparing the Next Generation of the Nation towards Global Era
}

\author{
Limas Dodi $^{1}$, M. Dimyati Huda ${ }^{2}$, Sufirmansyah ${ }^{3}$ \\ Institut Agama Islam Negeri Kediri, Jl. Sunan Ampel No 7, Ngronggo, Kediri, Jawa Timur, \\ 64127 Indonesia ${ }^{1,2,3}$ \\ \{ade_elfa@ymail.com¹,dimyatihuda64@gmail.com², mas.imansyah@gmail.com³
}

\begin{abstract}
Today's social problems are increasingly showing unique complexity. The issue of terrorism that has its roots in understanding radical diversity is one of the biggest problems that occur. This is assumed to be a serious problem that is getting bigger due to technological developments that show extraordinary significance. However, this very rapid technological development is also influenced by borderless world, as well as the main characteristics of the global era. Without being accompanied by a strong quality of faith, the next generation can take the wrong step in utilizing the technology. And that could inflame radical ideals and will plunge their lives towards global chaos in the future. This article will explore philosophically about the application of moderate Islamic education as a strategic step in preparing the nation's future generation towards a global era, where it is one of the options that can be pursued in order to carry out the vision of religious moderation which has been increasingly heavily campaigned by the Ministry of Religion of the Republic of Indonesia (RI Ministry of Religion). Based on several analyzes that have been carried out, the vision of religious moderation can be done in many ways, one of which is by applying moderate Islamic education. This has become a strategic option because education in Indonesia has a very vital position, where the government policy requires all Indonesians to study for 12 years. Through this moderate Islamic education, the future generation of this nation is expected to be able to maintain and improve the quality of their faith so that they can control and keep themselves from the danger of radical understanding. With such self-control, the nation's next generation will have a clear vision of life and can make the right decisions when faced with global problems.
\end{abstract}

Keywords: Islam; Religious; Moderate; Education; Next Generation; Global Era

\section{Introduction}

The global era has shown various impacts in human life. Many significant changes occur when today's situation is compared to the situation in the past. The increasingly complex 
problems faced by humans make various circles worry, especially for the younger generation. Those who are still in a period of development and identity searching are forced to adapt to a life that is borderless and very free. If they do not have sufficient quality, then it can be ascertained that they will fall prey to life choices. And more worryingly, they could be involved in complicated problems such as understanding radical diversity and leading to acts of violence that lead to acts of terrorism.

Radicalism itself comes from the root word radix (Latin) which means root. In another sense, radicals are also often interpreted as fundamental. If calling radicalism in religion is synonymous with religious fundamentalism. Another understanding that is synonymous with the word radicalism is fanaticism, extremism, militism, and others. The radical word is also commensurate with the words liberal, reactionary, progressive and others [1].

Violence acts today often occur everywhere, either in the form of attacks on certain individuals or groups, destruction, riots, student discipline, clashes and student chaos, murder, even bombs. All of this not only affected material, but also lost human lives. Admittedly the idea of the radicalism movement at first was to achieve change, but the way to achieve this goal was done by force with violence that could cause riots and or horizontal conflicts in the community, this meant the high intolerance behavior in Indonesia. Among the factors that cause radicalism in Indonesia, namely the external factors namely the influx of the influence of the atrocities of the Islamic State of Iraq and Syria (ISIS) or the Islamic State of Iraq the Levant (ISIL) and internal factors, namely the emergence of radical religious organizations, including the Indonesian Mujahidin Council / MMI, East Indonesian Mujahidin (MIT) and Jamaah Islamiyah / JI, Negara Islam Indonesia (NII). These groups are allegedly involved in movements that have the potential to carry out acts of radicalism and terrorism [2].

In addition, these actions were also triggered by false radical religious understanding, unequal socio-economic conditions, between minority groups (established) and the majority (disadvantaged), widespread poverty and unemployment, gaps and political and security instability due to various ethnic groups. religion and class. The tendency to strengthen intolerance among schools, the lifestyles of lifestyles that are increasingly materialistic, fermissive and pragmatic. More tragically, radical is not only carried out by the lower classes, but also by elite groups, people of all ages, and not only men, but also women. Very dilemmatic, because they do not seem to understand the main purpose of Islam, which is the blessing for all nature (rahmatan lil 'alamin). Education is always looking for solutions by taking the middle way, not extreme or excessive, love peace and always act rationally, through the right reasoning.

However, having a radical attitude and understanding does not have to make a person fall into the mind and act of terrorism. There are other factors that motivate someone to join the terrorism network. The motivation is caused by several factors. First, domestic factors, namely domestic conditions such as poverty, injustice or feeling disappointed with the government. Secondly, international factors, namely the influence of foreign environment which provides the driving force for the growth of religious sentiment such as global injustice, arrogant foreign policy, and modern imperialism of the superpower. Third, cultural factors that are closely related to superficial religious understanding and narrow and lexical interpretation of scripture (harfiyah). Radical attitudes and understanding and motivated by various factors above often make one choose to join terrorism actions and networks.

There are many kinds of understanding in defining terrorism. From a variety of definitions by experts and scientists as well as the basis for a country, it contains at least three things: first, the method, namely using violence; second, targets, namely random civilian casualties, and three objectives, namely to spread fear and for the sake of social and political change [3]. 
However, the majority of acts of violence committed in acts of terrorism are motivated by a radical understanding of their religiosity.

The next generation of the nation gets the challenges of life that are extraordinarily heavy, especially if it is associated with a radical understanding of diversity. This is also motivated by the existence of social settings that are indeed developing very rapidly as the global era progresses today. However, education is considered capable of directing the mindset of the nation's next generation. This is in accordance with the term of education stated in Law Number 20 of 2003 concerning the National Education System, where education is defined as conscious and planned effort to realize the learning atmosphere and learning process so that students actively develop their potential to have religious spiritual power, self-control, personality, intelligence, noble character, and skills needed for himself, society, nation and State [4].

This understanding contains several meanings, namely First: education must be able to develop all the potential that exists in every human being. Human potential in general is divided into three things, namely intellectual potential, moral potential or personality, and motoric potential. That is, education is not justified only developing intellectuals that deny moral and motoric alone or vice versa. Second, the target of education is the achievement of religious spiritual power, being able to control oneself, have personality, and have the intelligence, morals, and skills needed for himself, society, nation, and country [5]. This is in line with the function of national education formulated in Article 3 of Act Number 20 of 2003 concerning the National Education System.

\section{Method}

The assumption brought in this article is that the application of moderate Islamic education can be used as a basis for the vision of religious moderation. Because thus, the next generation of the nation is expected to be able to improve its quality in order to be able to respond to challenges in the global era, and be able to make the right decisions so that they will no longer be swayed by doubts in choosing their way of life. This article is compiled based on a compilation of several relevant references, so that the approach used is a qualitative type of literature study approach. This is done in order to obtain a valid synthesis through a combination of various interconnected sources in order to get a more comprehensive picture of the concept of religious moderation that will be projected to be able to be sufficient provision for the next generation in facing the challenges of life in the global era.

\section{Results and Discussion}

This article results some point of view from the holistic concept of deradicalization. Concrete efforts that can be done to equip the next generation of the nation in forming a formidable person who is able to protect themselves from the dangers of radical thinking in religion, can be done in various ways. The implementation of moderate religious values, or in its popular language in Indonesia, is the spirit of grounding religious moderation, can be applied through the strategic position of educational institutions. Internalizing the values of wasatiyah in understanding the teachings of Islam can be incorporated into various teaching materials delivered in the learning process. In addition, cultivating moderate religious habits 
can also be done. In fact, the addition of religious material as a follow-up to the vision of religious moderation can also be conveyed in extracurricular activities.

\subsection{Radicalism as a Problem in the Global Era}

Lately radical threats and actions have always sprung up by certain groups, which can disturb the public and threaten the pillars of citizenship that bind us together in a unitary state. They belong to a hard-core, stubborn, violent, hard-line group, always prejudiced, narrow and rigid. As if the space for diversity in the country was stuffy with violence and brutality. This radical group translates jihad with war, whereas, jihad does not mean war, but it tries earnestly to improve society, and Islam is a religion of peace [6].

Radicals are interpreted as, "thoroughly, all out, very demanding change, progress in thinking and acting". The word ism is the final affix meaning meaning / flow. Radicalism is a hard school / movement / movement that demands change. Against such understandings the Ministry of Religion does not legitimize, this radical attitude, as well as the extreme and exclusive nature, but must develop moderate religious understandings [7]. In Islam, the term radical is not known, but there is the term ghuluw which means excessive attitude, and the facade is like damage. As for the facade here is an action that can cause social system disruption causing loss of soul and property [8]. Radical attitudes usually lead to extreme activities.

Rubaidi described five characteristics of the radicalism movement. First, making Islam a final ideology in regulating individual life and also state political governance. Second, the Islamic values adopted adopt the source - in the Middle East - as it is without considering social and political developments when the Koran and hadith are present on this earth, with current local realities. Third, because attention is more focused on the text of the Qur'an and hadith, this purification is very careful to accept all non-Islamic cultures (Middle Eastern culture) including being careful in accepting local traditions for fear of interfering in Islam with heresy . Fourth, rejecting non-Middle Eastern ideologies including Western ideologies, such as democracy, secularism and liberalism. Again, all the rules that are set must refer to the Qur'an and hadith. Fifth, this group movement is often at odds with the wider community including the government. Therefore, sometimes there is even physical ideological friction with other groups, including the government [9].

The phenomenon of violence in the name of religion, which is often known as religious radicalism [10], is increasingly apparent, which in turn is the background of the terrorism movement which always haunts and becomes a problem now faced by countries in the world, including Indonesia. Understanding like this is actually not caused by a single factor that stands alone. Social, economic, environmental, political and even educational factors contribute to influencing religious radicalism. However, religious radicalism is often driven by narrow religious understanding, feelings of pressure, hegemony, psychosocial insecurity, and local and global injustice [11]. This movement gained many followers among the young generation of Islam who grew up under the system of nationalist-secular government [12].

Azyumardi termed radicalism as extreme exclusivism, where this type of exclusivism is very closed, dichotomy (right-wrong), and radical. This group only justifies its own school of thought, blaming, misleading, and denouncing other schools [13]. Islam is normativedoctrinal, expressly denies and rejects an exclusive attitude. But it offers solutions that are more realistic, practical, constructive and conducive to fostering a climate of tolerance, sympathy and tolerance between one group and another [14]. In a pluralistic life there should be a willingness to accept other groups equally as a whole, regardless of cultural, ethnic, 
gender, language or religious differences [15]. Even this is a true affinity of diversity in the bonds of civilization, and is also a necessity for all humanity [16].

Extreme can be grouped into: first, extreme right (radical). In the interpretation method, that is too holding on to the birth of the text and ignoring the benefits or the purpose behind the text (literal). Second, extreme left (liberal). He holds on to inner meaning. Both of these understandings are intolerable deviations. In dealing with this, a method is needed to mediate the two, without aborting the meaning of the birth of the text, by considering the benefit or inner meaning behind the text that is relevant to the times. This is called the middle / moderate method.

Two things that are in extreme contradiction are called antithesis, both opinions, theories, realities, conditions and so on. To overcome extreme opposition we have to do a synthesis, which is an attempt to integrate two contradictory things into one or a middle way by taking part of the positive elements of the thesis or anti-thesis. It is in this synthesis that we acquire new knowledge, even though by connecting positive things from thesis and antithesis. With the flow of this dialectic thinking, it can be emphasized that the thinking generated from synthesis is moderate, because it mediates two things that are diametrically opposed [17].

\subsection{Moderate Islamic Education as a Solution to Counter Radicalism}

Islamic education has generally seemed to be concerned only with vertical relations with the creator of Allah SWT in the form of worship alone, on the contrary less concerned with horizontal relations with fellow human beings, or without considering obligations to fellow human beings and the environment, in the sense of caring for the social and environmental environment life has been ignored. The relationship between humans and fellow human beings does not run intimate, does not establish close friendships, even become enemies, not empathy and sympathy for fellow human beings. As for moderate Islamic education, the Islamic values as a religion that rahmatan lil 'alamin put forward. Islam that brings grace, can cool, calm, love and tenderness to all people. Having a culture of mutual cooperation, please help, respect and respect each other. Always prioritize egalitarianism which views all people as equal and non-discriminatory in terms of religion, ethnicity, color, language, economic, social and other backgrounds. This condition will have the potential to overcome radicalism and extremism.

Today moderate Islamic education must be a top priority in preventing acts of radicalism and extremism, because Islam has been studied intact and faithful or comprehensive and comprehensive, which displays a middle ground so that it can coexist peacefully with other adherents of religion and religion, not partially disconnected. - half or half, which can make extreme, exclusive and intolerant [18]. Moderate comes from the word moderation which means to like the medium, avoid extreme views or actions, like very rational actions. In terms of Islamic education is called wasathiyyah, meaning the balance between two sides that are equally depraved; left and right, excessive (ghuluww) and ignorance (taqshir), literal and liberal, as well as the generous nature of being between stingy (taqtir / bakhil) and extravagant in nature (tabdzir) [19]. The attitude of the "middle way" (wasath) is what is expected to maintain balance in life, according to the words of the Prophet "Knowledge (Al-Qur'an) will always be carried on every generation by people who are moderate (' the title), they are the will preserve the Qur'an from their idiosyncratic penances, their vanity manipulation and their excessive (extreme) abuse.

Abu Al Hasan Ali Al-Bashri Al-Mawardi expressed the words of the philosophers, "the praiseworthy character is one that is in the middle position between two despicable traits, or good deeds are good that are in the middle position between the two evils." [20] Likewise, 
Lukman Hakim's presentation is the most advanced by all parties, including the government, namely moderation, "Moderation is how every religious person is radical (understanding rooted or comprehensive religious teachings), firmly holding his beliefs, but beliefs related to religious substance." [21] This opinion is also strengthened by Mohammad Abduhzen who said that religious education must be directed to efforts to "moderate" the attitude of diversity, namely being a believer is more useful and the best people. Religion must be formulated as a constructive solution and power that makes life happy, not as a destructive force and a miserable burden [22].

Moderate education always teaches to do very rational actions. Rational is translated from the word rational, meaning rational, reasonable, understanding [23]. Thus it can be understood in terms of the act or behavior carried out according to or in accordance with the mind, a healthy mind, carried out with full consideration, how the advantages and disadvantages, the positive and negative impacts, are not careless or reckless. A rationalist always starts or rests on a rational one, is very careful in acting, so the results will bring good luck to himself and others.

A rationalist will always act intelligently, think carefully and precisely, act with calculation, high curiosity, communicate effectively and empathetically, associate politely, uphold truth and virtue, love God and the environment [24]. Besides the rational, there is a higher one, namely supra rational, which makes sense even if it is not in accordance with the laws of nature, which is called logically. This logic includes the rational and the suprarational. Examples of Prophet Ibrahim being burned are not charred, this violates the law of nature, meaning it is illogical, but is it also illogical in the sense of being supra-rational? God made fire consisting of two elements of fire and heat. God can change the nature of fire from heat to cold. Reasonable and logical, the case of Ibrahim is an irrational, but logical case in a logical-supra-rational sense [25]. So Islamic education views truth as not from reason alone, because there are many other things, which cannot be reached by reason, to distinguish truth and error [26].

As such, actually the de-radicalization efforts through moderate Islamic education can be the answer to today's problems. The next generation of people who live in the global era need to be well prepared so that they are able to continue to compete optimally without having to be influenced by radicalism issues whose development is increasingly worrying for various parties.

\subsection{Concrete Steps of Deradicalization as Preparation for the Successive Generation of the Nation Towards Global Era}

The dissemination of movements, invitations, suggestions, or any information about antireligious radicalism is basically part of an effort to communicate the resistance to religious radicalism itself. Cutlip, Center and Broom say that effective information campaigns must be designed to suit the situation, time, place and audience [28]. This means relating to the selection of the right media and techniques. The word "designed" in this case can be attributed to an anti-radicalism information campaign that must be planned to suit the situation, time, place, and intended audience in the anti-radicalism campaign.

An information campaign is a series of planned communication actions with the aim of creating certain effects on a large number of audiences that are carried out on an ongoing basis over a period of time [29]. One of the characteristics of this information campaign is the existence of clear sources, namely the parties who are the initiators, designers, deliverers as 
well as those responsible for a campaign product that can be clearly known. This means that source credibility is important here.

The vision of religious moderation echoed by the Ministry of Religion shows that the spirit of Islamic moderation should be fought together, including efforts to provide moderate Islamic education through educational institutions. Educational institutions are a very strategic place to instill the values of Islamic moderation. The students in the future will lead to increasingly pluralistic and complex situations or conditions of the community or country. They as the nation's next generation are in the midst of an environment with diverse backgrounds, both cultural and religious differences. Investigation institutions are obliged to form an inclusive, tolerant and open mindset and attitude in seeing the differences that exist around them.

Although some time ago there were indications that there was a radical side in the Islamic Education subject book [30], it did not necessarily make the educational institution untrustworthy in fostering a vision of religious moderation. Precisely with the existence of these cases, educational institutions are expected to respond quickly to indications of radical understanding so that the material presented to students is completely free from things that can plunge into thinking error.

Deradicalisation efforts can be done in various ways. Because after all, educational institutions have a strategic position in instilling the values of religious moderation in the future generation of this nation. For example, Sa'dulloh proposed a pattern of implementing de-radicalization efforts through the selection of teaching materials containing moderate Islamic concepts [31]. This also shows that actually the efforts to deradicalization can be internalized through various scientific fields, not just in lectures / Islamic studies.

In addition, efforts to minimize the emergence of radical religious understandings can also be done through several other efforts. The intended effort is to provide an adequate explanation of Islam, promote dialogue in the study of Islam, monitor religious mentoring activities and materials, and introduce and implement multicultural education [32]. This is important considering the Indonesian nation is a pluralistic nation which consists of various races, ethnicities, cultures and ethnicities which are extraordinarily abundant. Thus, multiculturalism education is considered as a necessity in order to achieve universal understanding of tolerance.

In other references, there are at least two strategies that can be implemented by educational institutions in realizing religious moderation. First is the academic strategy, where it refers to the curriculum and instructions for developing several programs that have been established. This strategy includes holding additional curriculum hours, enhancing additional curricula, enhancing several instructional programs, and intensifying activities oriented towards increasing religious understanding. Second, the non-academic strategy. Non-academic strategies refer to extracurricular activities and additional activities outside school hours. The head of the madrasah together with the deputy head of the madrasah and other teachers carried out various programs that supported learning outside the madrasa hours. Free extra-curricular programs are chosen by students. Students are free to choose according to their interests and time. The programs offered are quite diverse including sports and arts [33].

Regarding the implementation in the non-academic domain, the concept of deradicalization through religious extracurricular can also be tried. This is based on research conducted by Panji and Endis, which after carrying out ongoing research concluded that the addition of explanations of religious materials given in extracurricular sessions can be an alternative in understanding students about Islamic moderation and at the same time minimizing the emergence of radical understandings [34]. Normatively, the addition of moderate religious material can certainly add insight and strengthen the understanding of 
proportional diversity. This can be used as a solid footing in counteracting the understanding of radicalism.

Actually the internalization of moderate Islamic values can also be started from the smallest part of the community, namely the family. The role of the family is vital in preparing their children to have proportional religious understanding. Because of the proportional religious understanding will be born superior individuals and have a personality that has character and is not easily swept away in radical issues. In this case, harmonization between father and mother as a nuclear family can be a very strong foundation in providing a moderate religious understanding [35].

Religious radicalism can only be opposed by religious anti-radicalism. The process of fighting religious radicalism can be done with various things, one of them through information campaigns in various forms. The information campaign against religious radicalism is basically a process of disseminating information to counter religious radicalism by going through various stages of planning. Communication planning strategies against religious radicalism are related to the objectives of the implementers.

Communication strategy planning includes the dimension of determining the vision and mission to be achieved, analyzing the situation, determining the target audience, choosing the communication target, building the issue and message framework, selecting the delivery strategy and device, and evaluating the success of the information campaign against religious radicalism. If all stages are implemented, then the accuracy of the information campaign carried out can be maximized to the target audience and can encourage the achievement of the objectives of the campaign itself [36]. Therefore, the vision of Islamic moderation must pay attention to this matter so that the contents of moderate Islamic understanding can be conveyed well to the next generation of the nation.

Prevention of radicalism is not only the responsibility of the government but also the joint responsibility of all components. Prevention strategies that must be carried out should use two ways, namely a hard approach in the form of repression and law enforcement against terrorists so that they can be legally compliant according to the prevailing laws and soft approaches in the form of guidance to the community (to anticipate the potential of radicalism) and raising terrorist prisoners and ex-terrorist prisoners by de-radicalizing both socially and individually and monitoring and pursuing terrorist funds (follow the money). This approach is in line with the proactive law enforcement strategy so that the possibility of taking preventive measures can be sought early [37].

From these various perspectives, the assumption of the author is increasingly powerful that actually the efforts of deradicalization are the responsibility of all parties. In order to prepare the nation's projected future generation to be a formidable person and not easily dissolved in chaos and global problems, the effort to free their thinking from a radical understanding must be pursued as much as possible. In this way, they will be able to face global competition more effectively, which in turn will be able to advance the Indonesian civilization in the future.

One global issue that has increasingly made people anxious in the international world is religious radicalism. This issue is deeply rooted, so it is very difficult to destroy. Even in the last few decades, acts of terrorism originating from religious radicalism increasingly surfaced. This is one of the challenges that must be overcome immediately. One alternative that can be done is to take various preventive measures to prevent radicalism.

Moderate Islamic education is expected to be able to be socialized optimally to the public massively, internalized, implemented, so that it becomes a mental attitude (personality) of others, as well as being a istiqamah applicable character and difficult to be swayed by any situation [38]. In this case it must get the support of religious leaders, community leaders and 
adat to become the vanguard force in representing friendly and progressive Indonesian Islam, once as a moral force to stem and fight all forms of radicalism and extremism.

Actually, from all of these deradicalization efforts, it is directed to one orientation, which is expected to be able to produce the next generation of the nation who have a good personality. The next generation of this nation will be projected to be able to compete internationally, so that it can advance the nation's civilization. Because after all, superior quality of self and not easily influenced by extreme ideologies will be very helpful in achieving the desired end goal, namely to advance the nation's civilization.

\section{Conclusion}

The global era forces all nations to immediately improve, especially in terms of the development of their civilization. This is because the mobilization and development of technology is running very fast. If a nation cannot adapt to the conditions in the global era, then surely the nation will be far behind. The development of civilization is very closely related to the quality of individuals from each country in the world. The next generation of the nation is the main driving force as well as a vital fulcrum for the country's progress. Therefore they must be well prepared in order to be able to compete in a world without limits like today.

To smooth things out, of course, good cooperation is needed from various parties. This is because moderate Islamic education must be guarded continuously by all components of this nation, starting with families, schools and the community in general. The policies taken by the government must also support this effort, because the government has sufficient power to enforce certain policies. Therefore, the essence of all these efforts is that there must be harmonization of all circles in order to prepare the next generation of the nation to face the global era.

\section{References}

[1] Muhammad, Hasyim et.al. 2015. Diskursus Deradikalisasi Agama: Pola Resistensi Pesantren terhadap Gerakan Radikal. Jurnal Walisongo, 23(1) pp. 197.

[2] This problem has also been highlighted by Masnur Alam. For exploration, see Alam, Masnur. 2017. Studi Implementasi Pendidikan Islam Moderat dalam Mencegah Ancaman Radikalisme di Kota Sungai Penuh Jambi. Islamika, 17(2) pp. 17-40.

[3] Kushner, Harvey W. 2003. Encyclopedia of Terrorism. Sage Publication, pp. xxiii.

[4] Undang-Undang Nomor 20 Tahun 2003 about Sistem Pendidikan Nasional, Article 1 Paragraph 1.

[5] Muchith, M. Saekan. 2016. Radikalisme dalam Dunia Pendidikan. Addin: Ilmu Sosial dan Keagamaan, 10(1) pp. 167-168.

[6] Naik, Zakir. 2017. Republika 22 Maret, pp. 12.

[7] Rachman, Budhy Munawar. 2004. Islam Pluralis, Wacana Kesetaraan Kaum Beriman. Paramadina, pp. 31.

[8] The word ghuluw is also mentioned in Q.S. Al-Baqarah [2]: 205.

[9] Rubaidi, A. 2010. Radikalisme Islam, Nahdlatul Ulama; Masa Depan Moderatisme Islam di Indonesia. Logung Pustaka, pp. 63. 
[10] Many other terms are also often used to refer to radicalism, such as fundamentalism, revivalism, extremism, militism, hardliners, etc. See Zada, Khamami. 2002. Islam Radikal: Pengumulan Ormas-ormas Islam Garis Keras di Indonesia. Teraju, pp. 13-16. See also Euben, Roxanne L. 2002. Musuh dalam Cermin: Fundamentalisme Islam dan Batas Rasionalisme Modern. Serambi, pp. 41. For further information, read Tibi, Bassam. 2000. Ancaman Fundamentalisme: Rajutan Islam Politik dan Kekerasan Dunia Baru. Tiara Wacana, pp. 241.

[11] Purwanto, Wawan H. 2007. Terorisme Undercover: Memberantas Terorisme hingga ke Akar-akarnya, Memungkinkah? CMB Press, pp.15.

[12] Jurgensmeyer, Mark. 2003. Terorisme Para Pembela Agama. Terawang Press, 2003), pp. 16.

[13] Azra, Azyumardi. 1998. Konflik Baru Antar Peradaban: Globalisasi, Radikalisme dan Pluralitas. RajaGrafindo Persada, pp. 224.

[14] Abdullah, M. Amin. 2000. Dinamika Islam Kultural Pemetaan Atas Wacana Keinlaman Kontemporer (Bandung: Mizan, pp. 75.

[15] Azra, Azyumardi. 2007. Merawat Kemajemukan Merawat Indonesia. Institute Pluralism and Multikulturalism Studies (Impulse) dan Kanisius, pp. 13.

[16] Rachman, Budhy Munawar. 2004. Islam Pluralis, Wacana Kesetaraan Kaum Beriman. Paramadina, pp. 31.

[17] Qomar, Mujamil. 2005. Epistemologi Pendidikan Islam dari Metode Rasional hingga Metode Kritik. Erlangga, pp. 2.

[18] For further exploration, read Azra, Azyumardi. 2007. Merawat Kemajemukan Merawat Indonesia. Institute Pluralism and Multikulturalism Studies (Impulse) dan Kanisius, pp. 13.

[19] Hanafi, Muchlis M. 2013. Moderasi Islam: Menangkal Radikalisasi Berbasis Agama. Ikatan Alumni al-Azhar dan Pusat Studi al-Qur'an, pp. 50.

[20] Al-Bashri, Abu Al Hasan Ali. 2002. Etika Agama dan Dunia Memahami Hakikat Beragama dan Berinteraksi di Dunia, Terj. Ibrahim Syuaib. Pustaka Setia, pp. 112.

[21] Republika, Selasa, 21 April 2015: 21.

[22] Kompas, Sabtu 2 Mei 2015: 6.

[23] Echols, John M. and Shadily, Hassan. Kamus Indonesia Inggris, pp. 466.

[24] Samani, Muchlas 2013. Konsep dan Model Pendidikan Karakter. Remaja Rosdakarya, pp. 51.

[25] Tafsir, Ahmad. 2008. Filsafat Pendidikan Islam. Remaja Rosdakarya, pp. 17.

[26] Ramayulis. 2004. Ilmu Pendidikan Islam. Kalam Mulia, pp. 111.

[27] Muhaimin. 2004. Paradigma Pendidikan Islam Upaya Mengefektifkan Pendidikan Agama Islam di Sekolah. Remaja Rosdakarya, pp. 179.

[28] Cutlip, Scot M. et.al. 2009. Effective Public Relation, Terj. Tri Wibowo. Prenada Media Group, pp. 10.

[29] Venus, Antar. 2009. Manajemen Kampanye. Simbiosa Rekatama Media, pp. 7.

[30] The full description can be seen in the results of the study from Hasniati. 2017. Analisis Muatan Radikalisme dalam Buku Teks Pendidikan Agama Islam (PAI) SMA. UIN Jakarta: Thesis.

[31] Muzammil, Sa'dulloh 2015. Upaya Pencegahan Radikalisme Agama dan Terorisme melalui Pemiliihan Tema Bahan Ajar pada Mata Kuliah English for Islamic Studies. At-Turats, 9(1) pp. 23-33. 
[32] Munip, Abdul. 2012. Menangkal Radikalisme Agama di Sekolah. Jurnal Pendidikan Islam, 10(1) pp. 159-181.

[33] This information was adapted from Halik, Abdul. 2016. Strategi Kepala Madrasah dan Guru dalam Pencegahan Paham Islam Radikal di Madrasah Aliyah Negeri (MAN) Mamuju. UIN Makassar: Thesis.

[34] Rahman, Panji Futuh et.al. 2016. Penerapan Materi Deradikalisasi untuk Menanggulangi Radikalisme pada Ekstrakurikuler Keagamaan. Tarbawy, 3(2) pp. 154165 .

[35] Zidni, Ervi Siti Zahroh. 2018. Kemitraan Keluarga dalam Menangkal Radikalisme. Jurnal Studi Al-Qur'an, 14 (1) pp. 32-43.

[36] Utomo, Gondo. 2016. Merancang Strategi Komunikasi Melawan Radikalisme Agama. Jurnal Komunikasi Islam, 6(1) pp. 93-128.

[37] Jazuli, Ahmad. 2016. Strategi Pencegahan Radikalisme dalam Rangka Pemberantasan Tindak Pidana Terorisme. JIKH: Jurnal Ilmiah Kebijakan Hukum, 10(2) pp. 197-209.

[38] Muhaimin. 2004. Paradigma Pendidikan Islam Upaya Mengefektifkan Pendidikan Agama Islam di Sekolah. Remaja Rosdakarya, pp. 179. 